\title{
Municipal Employees' Perceptions of Service Delivery in Limpopo-South Africa: A Critical Need for Good Governance
}

\author{
Barry Hanyane ${ }^{1}$ and Goonasagree Naidoo ${ }^{2}$ \\ ${ }^{1}$ North West University, Potchefstroom, North West, South Africa, 2520 \\ E-mail: barry.hanyane@nwu.ac.za \\ ${ }^{2}$ University of South Africa, Pretoria, Gauteng, South Africa, 0003 \\ E-mail: naidog@unisa.ac.za
}

KEYWORDS Municipal Councillors. Municipal Officials. Local Government. Governance Principles. Governance Practices. Good Governance

\begin{abstract}
Public service delivery protests in post-apatheid South Africa has come to characterize community life at the local sphere of government. Negative consequences of corruption, maladministration, mismanagement of public resources and poor service delivery, all negatively impact good governance in South Africa's young democracy. This paper intends to investigate the perceptions of municipal employees regarding service delivery and governance at the local government level. More often in South Africa, the assessment of the perceptions of service providers regarding service delivery has received minimal attention at the local government sphere as compared to those of service recipients. This paper fills this gap through literature analysis and an empirical survey conducted among the service providers at municipalities in the Limpopo province to obtain an insight of the perceptions of critical role-players and to provide recommendations to improve service delivery at municipalities in South Africa. The study adopts both qualitative and quantitative methodologies.
\end{abstract}

\section{INTRODUCTION}

Since the transformation of the local government in the late nineties in South Africa, new challenges and problems have surfaced, posing a serious threat to the newly established democratic dispensation. These challenges and problems revolve around the need for improvements in the area of public service delivery, ensuring quality standards of urban and rural public service delivery, urban and rural development, and the establishment of urban and rural infrastructure to enable efficient and effective public service delivery. To this end, the government as represented by local authorities at this sphere of government, needs to realize the significance of establishing enabling or necessary conditions for the realization of effective and efficient urban and rural service delivery.

One such condition is the need to ensure that the infrastructure of urban and rural areas

Address for correspondence:

Barry Hanyane

Professor

North-West University

Potchefstroom Campus

11 Hoffman Street

Potchefstroom 2531, South Africa

Telephone: +27 182994332

Fax: +27 182994254

E-mail: barry.hanyane@nwu.ac.za (both physically and in terms of demographics) is improved. Areas such as clean water provision and proper sanitation, public transport, adequate housing, infrastructure maintenance and other services remain a critical area of concern. This, for instance, requires a total overhaul of the urban and rural infrastructure in order to enable accessibility to most public services and amenities. The local government sphere, which is closest to the residents and/or local consumers of public goods and services, should therefore create a viable environment wherein public resources are provided to local residents, local consumers, and/or public and private entities. This paper established the degree to which the various municipal employees, especially councillors of municipalities in the province of Limpopo perceive service delivery challenges.

This research initiative seeks to investigate the nature, significance and the public administration (utilitarian) value of basic service delivery and management in the aforementioned municipalities and the concomitant challenges thereof. The researchers in this project hold the view that without a proper service delivery strategy, and the adoption of good governance principles, practices and strategies for municipalities in South Africa effective and efficient public administration (public services) at local government level would not be possible. An attempt is 
therefore made at establishing the extent to which "good governance in service delivery" is meaningful and sustainable in the various municipalities in the Limpopo Province in South Africa. These municipalities are also responsible for basic service delivery, proper infrastructure and enabling conditions associated with proper municipal administration and management strategies must exist.

\section{Research Objectives}

The paper aims to achieve the following objectives:

- To investigate service delivery perceptions of the municipal employees at selected government municipalities in Limpopo province.

- To subsequently help bridge the existing gap in the literature on the assessment of the perceptions of service providers regarding service delivery in South Africa.

- To investigate the nature, significance and the public administration value of basic service delivery and management in the identified municipalities and the concomitant challenges thereof.

\section{Literature Analysis}

A balanced relationship between service delivery and governance is significant in the South African local or municipal government context. In the absence of effective governance, service delivery cannot be improved in these municipalities. However, effective governance alone will not end the service delivery dilemma faced by municipalities. However, it is maintained that service delivery can be significantly improved by good governance principles, practices and effective strategies. In terms of policy implementation in South Africa, the greatest challenges are with the municipalities at the local government sphere. The research undertaken by the researchers suggest that the disparity in municipal governance has a direct impact on service delivery to South African municipalities. However, some municipalities display relatively effective governance, while others display lack of good governance principles and good governance practices and service delivery performance (Heese and Allan 2012). Auditor-General SA (2013-2014) adds that there has been an im- provement in internal controls in terms of leadership and governennce, however, municipalities have shown very little progress in areas of financial and performance management controls.

According to the Auditor-General South Africa (2013-2014), the local government financial audit reported that only 58 of 325 audits, (40 of 268 municipalities and 18 of 57 municipal entities), that is, seventeen percent received clean audits. Although this figure shows an improvement compared to previous reports, overall it also indicates a poor state of the financial management in South African municipalities. This unhealthy financial status is further presented as follows: thirty-five percent of the audits received an unqualified opinion with findings, twenty-two percent received a qualified opinion and seventeen percent received a disclaimed or adverse opinion.

The reasons audits received qualified, adverse and disclaimed opinions is because they produced inadequate or missing supporting documents, received qualifications in items such as property, infrastructure and equipment, qualifications in areas like revenue and receivables, as well as irregular expenditure, which is argued to have reduced, as well as an increase in unauthorized expenditure (Auditor-General SA 20132014). Heese and Allan (2012) indicated that there are two reasons for this dismal state of affairs in South Africa. "Incompetence of municipal workers is the first noted reason” (Naidoo 2009, 2010, 2011). The second significant factor is "the lack of political commitment, by key political decision-makers" (Naidoo 2009). Naidoo (2009) also identified the lack of effective internal controls to assist in effectively monitoring and evaluating service delivery projects.

As a result of this poor financial state in the local government, the delivery of services to communities, namely the provision of housing, water and sanitation, electrification, health and education, have proved disappointing in attempting to reduce poverty and address socioeconomic problems at municipalities (Holtzhauzen and Naidoo 2011). Over two decades after the end of apartheid in South Africa, more than fifty percent of communities do not receive acceptable delivery of public services, especially in rural communities (Naidoo 2009, 2010; Naidoo and Thani 2011). Auditor-General SA (2013-2014) places an emphasis on the significance of clean administration as a catalyst to drive service delivery. 
The South African local government's legislative framework demands that municipalities be more responsive and accountable for public service delivery (Naidoo 2012). Furthermore, there is a critical need to provide accessibility to services, especially with rural communities. It is therefore argued that the adherence of good governance principles (accountability, responsibility and accessibility) and the adoption of good governance practices (effective management of resources and the monitoring and evaluation of service delivery project) are critical in improving service delivery in municipalities in South Africa. It is therefore deemed necessary to provide a broad overview of service delivery at municipalities.

\section{Overview of Public Service Delivery at the Local Government Sphere}

A number of government-funded projects have been established, aimed at improving public service delivery at all spheres of government in South Africa (Public Service Commission 2007a; Naidoo 2009; Naidoo and Thani 2011; Holtzhauzen and Naidoo 2011). Despite the numerous efforts, service delivery in South Africa remains challenging, especially at the local government sphere (Public Service Commission 2007b; Naidoo 2009; Holtzhauzen and Naidoo 2011). According to The Institute of Risk Management South Africa - IRMSA (2015), the biggest failure of governance is mainly experienced at the local government level in South Africa. This just indicates the urgency of governance crisis, which has tremendously affected service delivery in municipalities.

Following the argument above, the Public Service Accountability Monitor (PSAM) of the United Nations (2010) indicates that a major obstacle to poor service delivery in South Africa, especially at local government, is poor governance practices, which includes rampant corruption, and poor performance by leadership and government officials in their management of public resources. "A lack of political will to act against underperforming officials is another critical factor resulting in poor service delivery” (Luyt 2008; Naidoo 2009). Following the lack of political will to take necessary actions, the ANCled government is slowly losing power and majority support as a result of poor governance, failed promises and endless allegations of corruption and nepotism, which consequently affects service delivery in municipalities (IRMSA 2015).

The poor management of public resources, such as human resources and finance translates directly into poor public service delivery, and thus undermines efforts to improve and promote public service delivery (Naidoo 2009, 2010). The absence of good governance principles and practices, especially at the local sphere of the government in South Africa namely, accessibility to public services has led to frustration among local communities manifesting in violent service delivery protests, which have swept through South Africa since 1994 (Naidoo 2009, 2010).

The Department of Cooperative Governance and Traditional Affairs (COGTA) (2009) recognized a number of explanations for concern in municipalities, over poor public service delivery, including poor governance practices and a lack of the adoption of good governance principles (in the document, titled Report of the State of Local Government in South Africa 2009). These issues include, "poor ability of councilors to deal with the demands of local government, inadequate accountability measures and support systems and resources for local democracy, poor compliance with regulatory and legislative frameworks, tensions between the political and administrative interface, lack of clear distinction between the legislative and executive, and insufficient separation of powers between municipal councils and political parties" (COGTA 2009; Naidoo 2009, 2010).

Naidoo (2009) and Holtzhausen and Naidoo (2011) revealed, "Party-political factionalism and polarization has led to the deterioration of municipal functionality and public service delivery." COGTA (2009) further indicated that local communities in South Africa are particularly disgruntled with "the poor institutionalization of systems, poor service delivery and poor political and administrative governance" (COGTA 2009). Nepotism, patronage and corruption has led to a lack of citizen confidence and trust in local government, as the municipal accountability system is seen as ineffective and inaccessible to citizens (COGTA 2009; Naidoo 2009). This has translated into modest public service delivery, which has resulted in an escalation of community dissatisfaction. Good governance principles and practices are therefore critical to promote and improve public service delivery (COG- 
TA 2009; Naidoo 2009; Holtzhausen 2010; Holtzhausen and Naidoo 2011). This is also imperative to curb violent public service delivery protests. Nonetheless, it is critical to analyze the data collected from the survey of municipal officials and councilors of the Limpopo Province with respect to service delivery.

\section{METHODOLOGY}

The method adopted in this research project was based on an empirical analysis embedded in quantitative and qualitative methodologies. The scale and extent to which the perceptions of municipal councillors elected after the May 2011 municipal elections are received and interpreted are based on calculating the degree of challenges on governance-related matters and service delivery. A quantitative methodology was therefore employed. In this instance, a questionnaire (based on a purposive sampling method) was drawn and administered to approximately 40 municipal councilors and salaried officials of various municipalities (local sphere of government) in the Limpopo Province of South Africa. Furthermore, content analysis (embedded in qualitative methodology) of policies and documented procedures at a local government sphere were analyzed in relation to the findings of the survey on municipal councilors and official's perceptions on service delivery and governance issues.

As a result, both qualitative and quantitative approaches were adopted in this study. A qualitative research method entails the use of content analysis relying on primary as well as secondary sources of data for information (policies, by-laws, structural interventions and procedures). This means that content analysis as a qualitative research method was used as a basis of investigation in this study. The focus was also directed at testing existing theories on local issues. The concept 'perception' is used as a variable. According to Creswell (1994), the intention of such a study is to develop generalizations that contribute to the theory and that enable one to better predict, explain and understand some phenomena. These generalizations are enhanced if the information and instruments used are valid and reliable. Secondary sources such as books, articles, journals and others listed in various sections of this research paper were utilized. Case studies, where relevant, were used.

The research questionnaires used in this survey were interpreted, captured and analyzed by the University of South Africa's division of Academic Research Support Unit (ARSU). The writers-cum-researchers of this project simply provided commentary on the findings. These findings are reflected in the discussion hereunder.

\section{DATA ANALYSIS AND RESULTS}

As Table 1 indicates, about 40 municipal councillors and public officials were interviewed from various municipalities in the Limpopo province, 21 being male respondents who were either public officials or municipal councilors. The remaining 19 respondents were female municipal councilors or public officials employed by various municipalities in the Limpopo Province. The dominance of male councilors and/or public officials can be attributed to many historical factors such as gender inequality in South Africa. As a predominatly peri-urban and mostly rural background, the Limpopo Province has long been dominated by some form of partriachic labor dispensation.

Table 1: Sex group by category

\begin{tabular}{lc}
\hline Gender of respondents & Number of respondents \\
\hline Male & 21 \\
Female & 19 \\
\hline
\end{tabular}

Owing to the prevailing dominant cultural influence bordering on conservative and transitional practices, the role of women in areas such as politics and positions in public service has suffered and has disadvantaged capable women in the province. It is the researcher's observation that women in the government and to a large extent politics, have to do more to prove their worth in the job market. This state of affairs prompted the researchers to ask important questions in relation to the status of the respondents. Given, municipal councillors are usually expected to serve a term of five years. Some municipal councillors tend to serve a second term of five years unless redeployed elsewhere in public services or another municipality. Table 2 focuses on the aforementioned area of investigation.

In the sample of municipal councilors and officials interviewed, 32 respondents said they 
Table 2: Employment status of respondents

\begin{tabular}{lr}
\hline Employment status & Number of respondents \\
\hline Municipal councilor & 1 of 32 = deployed \\
Municipal official & \\
Unemployed & 5 \\
\hline
\end{tabular}

were municipal councilors. Of the 32 municipal councilors, one councilor was a deployed municipal councilor from his or her political party. Five other respondents said they were municipal officials. The other three respondents were, at the time of conducting the survey, unemployed. Respondents were also asked about the status of their residency. Table 3 reflects the results of this question.

About 34 respondents in the survey said they were permanently staying in their respective municipalities in the Limpopo Province. Only five respondents said they were not permanent residents of the communities they serve. This could be attributed to the principle of the redeployment of party cadres in the case of the ruling party, the African National Congress (ANC), or municipal officials relocating to a municipality of choice to seek and secure employment. Only one respondent was not sure of his or her status according to Table 3 . Respondents were also asked about the duration of their permanent residency. In this respect results have been interpreted in Table 4.

Besides the need to measure the permanence of the respondents in their respect areas of habitation, the survey also focused on the duration of the mentioned permanency. This duration of permanency was measured in months and/or years stayed in a particular local municipality. According to the survey results, three respondents said they have been staying in their areas of habitation for more than 42 years. The same number of respondents also committed themselves to have been staying in their locality for about 15 years. Respondents were also probed about whether they pay for municipal services or not. Table 5 contains the results of this inquiry.

Table 3: Permanency of residency of respondents

\begin{tabular}{lr}
\hline Residence status & Number of respondents \\
\hline Permanent residents & 34 \\
Temporary residents & 5 \\
Unsure & 1 \\
\hline
\end{tabular}

Table 4: Duration of residency by respondents

\begin{tabular}{lc}
\hline Period of a month(s)/year(s) & Number of respondents \\
\hline 49 & 1 \\
45 & 1 \\
42 & 3 \\
41 & 1 \\
40 & 2 \\
37 & 1 \\
33 & 3 \\
32 & 2 \\
31 & 2 \\
30 & 1 \\
29 & 1 \\
27 & 1 \\
26 & 1 \\
20 & 1 \\
16 & 1 \\
15 & 3 \\
10 & 2 \\
9 & 1 \\
6 & 1 \\
5 & 2 \\
1 & 1 \\
months & 2 \\
\hline
\end{tabular}

Table 5: Municipal service rate payment by respondents

\begin{tabular}{lc}
\hline Payment of municipal services & $\begin{array}{c}\text { Number of } \\
\text { respondents }\end{array}$ \\
\hline Ratepayers & 27 \\
Non-ratepayers & 9 \\
\hline
\end{tabular}

About 27 respondents replied to the survey as municipal ratepayers. A total of 9 respondents said they were not service ratepayers. The reason(s) for this reality was/were not stated since no such inquiry was catered for in the questionnaire. However, respondents who regarded themselves as municipal ratepayers were asked about the type of municipal services they pay for. Their responses are summarized in Table 6 .

Table 6: Types of municipal services paid by respondents - protection services

\begin{tabular}{lr}
\hline $\begin{array}{l}\text { Municipal service } \\
\text { Protection service }\end{array}$ & $\begin{array}{c}\text { Total number of } \\
\text { respondents paid }\end{array}$ \\
\hline \multicolumn{2}{c}{ Amount Paid Monthly } \\
\hline Distribution of respondents & 5 \\
\hline 2 & Amount paid \\
1 & 100 \\
1 & 109 \\
1 & 125 \\
\hline
\end{tabular}


About five respondents said they paid for protection services, which included local community protection services contribution such as donations. Two of the respondents suggested spending around R100 per month on this type of service(s). The other three respondents spend approximately R109, R125 and R270 respectively for protection services. A further question around the payment of municipal hygienic services such as water and sanitation was also asked. In this instance, more respondents replied as presented in the results in Table 7.

Table 7: Type of municipal services paid by respondents - hygienic services

\begin{tabular}{|c|c|}
\hline Municipal service & $\begin{array}{l}\text { Total number of } \\
\text { respondents paid }\end{array}$ \\
\hline Hygienic services & 17 \\
\hline \multicolumn{2}{|c|}{ Amount Paid Monthly } \\
\hline Distribution of respondents & Amount paid \\
\hline 1 & 45 \\
\hline 1 & 50 \\
\hline 3 & 100 \\
\hline 1 & 120 \\
\hline 1 & 150 \\
\hline 1 & 250 \\
\hline 1 & 257 \\
\hline 1 & 275 \\
\hline 3 & 300 \\
\hline 1 & 400 \\
\hline 1 & 500 \\
\hline 1 & 580 \\
\hline 1 & 700 \\
\hline 1 & 270 \\
\hline
\end{tabular}

About three respondents mentioned spending approximately R100 per month in paying for municipal water and sanitation services in their areas of habitation. The same number of respondents mentioned to be spending around R300 per month in the same municipal service area. The remaining respondents revealed an expenditure pattern of an average of between R45 to R700 per month. The respondents also considered other service areas, such as energy services. Energy services such as electricity and gas were the focus of further inquiry. Respondents gave feedback captured in Table 8 .

In relation to responses of the respondents interviewed in the various municipalities in the Limpopo Province on matters related to the payment of energy services, varying degrees of responses were captured. In this instance, respondents who paid for such service(s) were record-
Table 8: Type of municipal services paid by respondents - energy services

\begin{tabular}{lr}
\hline $\begin{array}{l}\text { Municipal service } \\
\text { Energy services }\end{array}$ & $\begin{array}{c}\text { Total number of } \\
\text { respondents paid }\end{array}$ \\
\hline \multicolumn{2}{c}{ Amount Paid Monthly } \\
\hline Distribution of respondents & Amount \\
\hline 1 & paid \\
3 & 30 \\
1 & 100 \\
1 & 180 \\
1 & 200 \\
1 & 250 \\
2 & 300 \\
4 & 350 \\
1 & 400 \\
\hline
\end{tabular}

ed in this manner: four respondents said they paid R300 on average per month, another four respondents said they paid R500 per month, three respondents suggested paying around R100 per month on energy bills including electricity and/or gas, two respondents each paid between R250 and R400 respectively and one respondent paid R30 per month with the same number at R180, R200, R700 and R1000 each.

Other services that were likely to be paid for by the respondents also received attention. Table 9 captures the responses in relation to other possible services paid for by the respondents. Without committing to specific 'other services' the respondents offered the following results. Three respondents said they spend R200 in procuring other public services. About two respon-

Table 9: Type of municipal services paid by respondents - other services

\begin{tabular}{|c|c|}
\hline Municipal service & $\begin{array}{l}\text { Total number of } \\
\text { respondents paid }\end{array}$ \\
\hline Other services & 12 \\
\hline \multicolumn{2}{|c|}{ Amount Paid Monthly } \\
\hline Distribution of respondents & Amountp paid \\
\hline 1 & 19 \\
\hline 2 & 20 \\
\hline 1 & 25 \\
\hline 1 & 57 \\
\hline 1 & 70 \\
\hline 1 & 100 \\
\hline 1 & 107 \\
\hline 1 & 150 \\
\hline 3 & 200 \\
\hline
\end{tabular}


dents said they spend R20 each in respect of this public service responsibility. One person each was said to spend R19 to R150 on 'other' municipal services.

Respondents were expected to respond to the question of estimating the average total amount of money spent on paying for public services received per month. Such an amount is needed to reflect on the number of public services paid for and the final average total calculated. As reflected in Table 10, about seven respondents said they pay an average total of about R300 per month on public services delivered in their municipality. Two sets of three respondents estimate their total average at R500 and R1000 spending per month. About four sets of the respondents opted for an estimated expenditure of between R180 to R620 on public services estimated at between R180 per month and R250 per month and R400 per month and R620 per month.

Table 10: Type of municipal services paid by respondents - total in (R) (Rands)

\begin{tabular}{lr}
\hline Number of respondents & $\begin{array}{c}\text { Total number of } \\
\text { services in Rands }\end{array}$ \\
\hline 1 & 100 \\
1 & 120 \\
1 & 130 \\
2 & 180 \\
1 & 219 \\
2 & 250 \\
1 & 300 \\
1 & 320 \\
2 & 370 \\
1 & 400 \\
3 & 482 \\
1 & 500 \\
2 & 550 \\
1 & 620 \\
1 & 625 \\
1 & 664 \\
1 & 700 \\
1 & 980 \\
1 & 1000 \\
1 & 1100 \\
1 & 1300 \\
\end{tabular}

Section B of the survey questionnaire dealt with municipal service delivery in relation to local government. A number of sub-total questions were prepared. These questions focused on matters such as municipal service delivery, municipal service delivery protests, interven- tions (if any) on curbing service delivery protests and the rating of service delivery performance by the municipalities of the Limpopo Province. Public administration-related issues and sociopolitical issues in Limpopo were also covered in this section. The first question in this section of the questionnaire focused on the respondents' occupation. The researchers needed to know whether indeed there were councilors and public officials in the sample chosen, and if all were actively employed at the time of the survey. Table 11 refers to the first question of Section B of the mentioned questionnaire dealing with the issues of occupancy.

Table 11 is a result of responses based on the question whether any of the respondents were municipal councilors. Of the 42 respondents, 29 said they were municipal councilors. Another group of respondents (five members to be exact) said they were not municipal councilors. The researchers can safely assume that they were salaried officials attached and working in various municipalities in the Province. It is noteworthy that all respondents were treated equally without prejudicing one group against the other. Both groups were the targets of municipal service delivery protests discussed and analyzed elsewhere in this paper. Table 12 depicts the results received in relation to the nature of the said municipal service delivery protests in the Limpopo Province.

Table 11: Occupation of the respondents (councillorship)

\begin{tabular}{lr}
\hline Respondents occupancy & Number of respondents \\
\hline Municipal councilors & 29 \\
Non-councilors & 5 \\
\hline
\end{tabular}

Table 12: Nature of service delivery protests

Nature of protests Number of respondents

Violent protests 10

Less violent 9

The respondents were asked about the prevalence, if any, and frequency of service delivery-related protests in their municipalities. To this end, the frequency and to a large extent, the nature of service delivery-related protests was the focus of question 2.7 of the questionnaire. More specifically, the question focused on whether such service delivery protests were vi- 
olent or not. About 10 respondents confirmed service delivery protests in their municipalities to be violent as opposed to 9 respondents who experienced a less violent service delivery protest in their municipalities. Question 2.7 focused on whether the violent nature of such service delivery protests resulted in damage to property and/or the death of a service delivery protester. Table 13 provides results to this question.

Table 13: Nature of service delivery protest(s) (2)

Death of protester/ damage of property Number of respondents

Death and/or damage

No death/ damage to property

Question 2.7 focused on whether the violent nature of such service delivery protests resulted in damage to property and/or the death of a service delivery protester. About 5 respondents confirmed service delivery protests in their municipalities resulted in either death of a protester or protesters and even damage to property. This confirms that some service delivery protests were violent as opposed to 13 respondents who experienced a less violent service delivery protest(s) in their municipalities with no death or damage of property. Respondents also rated the performance of their municipalities in relation to public service delivery. Table 14 showcases the results and interesting insights to this question.

The respondents were asked to rate the service delivery performance of their respective municipalities. In a Likert scale of 1 to 10 (1 to 3 denoting poor service delivery performance, 4 to 7 denoting moderate service delivery performance and 8 to 10 representing good to excellent service delivery performance) respondents

Table 14: Service delivery performance rating by respondents

\begin{tabular}{lr}
\hline Performance ratings & Number of respondents \\
\hline 1 & 1 \\
2 & 2 \\
3 & 2 \\
4 & 8 \\
5 & 13 \\
6 & 4 \\
7 & 4 \\
9 & 4 \\
\hline
\end{tabular}

were asked to rate their municipalities. 13 of the respondents held the view that their municipalities performed moderately well with a rating of 5 . 8 respondents rated their municipalities at 4, suggesting a lower moderate rating. Four respondents made the second highest rating of 8 . One respondent rated their municipality at 2, the other at 3 reflecting poor service delivery performance, four at 6 , and another four at 7 suggesting moderate service delivery, while two rated 9, suggesting good to excellent service delivery performance. Only one respondent gave a dismal 1 rating, bordering on extremely poor service delivery performance by his or her municipality. These results in the eyes of the researchers are central to the question posed in this paper: Are Limpopo municipalities governed well to promote service delivery goals and objectives? An analysis of these results suggests a strong presence of perceptions towards poor to moderate service delivery performance as seen by municipal councilors and public officials of Limpopo municipalities.

\section{CONCLUSION}

Public service delivery is imbued with pertinent challenges, hurdles and problems such as corruption, inefficiency, mismanagement of public resources and ultimately poor service delivery. Successful case studies are few and far and overshadowed by a plethora of poor examples or case studies nationally. Municipalities in the Limpopo Province of South Africa have in their numbers suffered from a malaise of the abovementioned negative spells, which has been evident from the survey undertaken. The empirical data presented in the paper, also supported by the evidence of the South African Auditor-General's Report on the status and audit of municipalities nationally of 2013/2014 points to the large scale negative consequences pertaining to public service delivery in municipalities.

Municipal officials and local councilors of the various provinces in the Limpopo Province in South Africa interviewed for this study were treated as both decision-makers and as ordinary members of their constituencies as they are expected to pay for public services and goods offered by their respective municipalities such as water, sanitation and other municipal tariffs and liabilities. In addition, the said evidence demonstrates the tentative relationship between ser- 
vice delivery and governance issues to be interdependent and mutually inclusive. This means that poor service delivery could be a serious reflection of the poor governance practice adopted and the lack of adoption of good governance principles.

\section{RECOMMENDATIONS}

This paper recommends that:

- Service delivery should be improved in all its facets-policy design, effective policy implementation of service delivery policies, monitoring and evaluation, constant feedback and improvement of service delivery.

- Good governance principles should be adopted and good governance practices and strategies should be implemented to promote and improve public service delivery at the local sphere of government in South Africa. The two variables should be treated interdependently and also as mutually inclusive.

- Capacity training and awareness initiatives should be implemented to improve the skills and competencies of municipal officials and councilors of various municipalities of the Limpopo province. Training in areas of municipal ethics, municipal governance practices, management of municipal resources, including municipal finance should be institutionalized and remain critical.

- Provincial and national government intervention should not be seen as a 'life-saving' act of response to the poor performing municipalities of the Limpopo Province in relation to service delivery and poor governance. Rather municipalities in the Limpopo Province should be held accountable for their actions and where possible, sanctions and corrective measures should be imposed to rid the scourge of poor public service delivery and appalling municipal governance.

\section{REFERENCES}

Auditor-General South Africa 2013-2014. Consolidated General Report on the Audit Outcomes of Local
Government: MFMA 2013-2014. South Africa: Auditor-General SA.

Creswell JW 1994. Research Design: Qualitative and Quantitative Approaches. London: Sage.

Department of Cooperative Governance and Traditional Affairs (COGTA) 2009. Basic Services Publication: Comparative Information on Basic Services. Pretoria: Department of Cooperative Governance and Traditional Affairs.

Heese K, Allan K 2012. Half of Municipalities Hopelessly Far Off Clean Audit Target. The Sunday Independent, July 29, 2012, P.4.

Holtzhausen N 2010. The role of ethics and values in securing public accountability. Administration Publica, 18(4): 261-280.

Holtzhausen N, Naidoo G 2011. Good governance as a strategy to promote service delivery in Local Government: The case for Soul City. Journal of USChina Public Administration, 8(1): 735-748.

The Institute of Risk Management South Africa (IRMSA) 2015. South Africa Risks Report 2015. $1^{\text {st }}$ Edition. Sandton: IRMSA.

Luyt D 2008. Governance, Accountability and Poverty Alleviation in South Africa. United Nations Social Forum, September 2008, Geneva, Switzerland.

Naidoo G 2009. Strengthening senior management skills in the South African Public Service: A rational for strategic leadership. Journal of Public Administration, 3: 3-15.

Naidoo G 2009. Leadership and Good Governance in Public Administration: A Transformative African Leadership Model for the South African Public Service. Germany: Verlag Publishers.

Naidoo G 2010. A critical need for effective leadership to promote effective service delivery by Local Government in South Africa. The case of rural Ramotshere Moiloa Municipality. Administratio Publica, 18(1): 106-123.

Naidoo G 2011. Adopting an appropriate leadership approach for the improvement of service delivery in the South African Public Service. African Journal of Public Affairs, 4(3): 45-59.

Naidoo G, Thani XC 2011. A critical need for an integrated leadership approach to improve service delivery by the South African Public Service. Journal of US-China Public Administration, 8(1): 1-15.

Naidoo G 2012. A critical need for effective leadership to promote effective service delivery by Local Government in South Africa. The case of rural Ramotshere Moiloa Municipality. African Journal of Public Affairs, 4(1): 25-35.

Public Service Accountability Monitor (PSAM). South Africa. From <http://www.psam.org.za> (Retrieved on 10 October 2010).

Public Service Commission 2007. Report on an Audit of Government's Poverty Reduction Programmes And Projects. Pretoria: The Public Service Commission. 